\title{
Spontaneous Pneumomediastinum in an Asymptomatic COVID-19 Patient
}

\section{Asemptomatik COVID 19 Hastasında Gelişen Spontan Pnömomediastinum}

Mehmet Veysel Coşkun, Selma Karaahmetoğlu, Sinem Karaoğlu, Sema Nur Arasan, Merve Öztürk

\section{Abstract}

Spontaneous pneumomediastinum is a rare and lifethreatening complication in patients with COVID-19. Although there are a few reports of spontaneous pneumomediastinum related to COVID-19 in literature, most involve patients who have been followed up in intensive care units (ICUs) or COVID-19 clinics for a period due to mild to severe COVID-19 disease. We present here a case of spontaneous pneumomediastinum that developed in an asymptomatic COVID-19 patient with no medical history.

Key words: Asymptomatic, COVID-19, pneumomediastinum.

\section{Özet}

Spontan pnömomediastinum, COVID-19 hastalarında nadir görülen ve hayatı tehdit eden komplikasyonlardan biridir. Literatürde az sayıda COVID-19'a bağlı spontan pnömomediastinum bildirimi bulunmakla birlikte, bu olgular daha çok orta ve şiddetli derecede COVID-19 hastalığı nedeni ile yoğun bakım ünitelerinde veya COVID-19 kliniklerinde bir süredir takip edilen hastalardır. Burada, bilinen dahili hastalığı olmayan asemptomatik bir COVID-19 hastasında gelişen spontan pnömomediastinum olgusunu sunduk.

Anahtar Sözcükler: Asemptomatik, COVID-19, pnömomediastinum.

Department of Internal Medicine, Ankara City Hospital, Ankara, Turkey

Submitted (Başvuru tarihi): 10.06.2021 Accepted (Kabul tarihi): 12.07.2021

Correspondence (iletişim): Mehmet Veysel Coşkun, Department of Internal Medicine, Ankara City Hospital, Ankara, Turkey

e-mail: coskun.veysel@gmail.com 
COVID-19 is still an urgent health problem around the world, despite more than a year having passed since the World Health Organization (WHO) declared a global pandemic on March 11, 2020. Due to the many different clinical manifestations associated with COVID-19, updates to literature become significant, especially for rare complications of COVID-19, for the management of patients. Spontaneous pneumomediastinum is an uncommon and life-threatening complication of COVID-19, however there have been few reports to date on spontaneous pneumomediastinum due to COVID-19 presented by different clinics in different countries $(1,2)$. While there have been studies published relating to COVID-19 patients with an absence of positive pressure ventilation, no underlying pulmonary disease and no smoking history, all have mild to severe COVID-19 infection, and have a history of ICU or COVID-19 clinic follow-up. In the present study we present a case of spontaneous pneumomediastinum due to asymptomatic COVID-19 infection in a young patient with no medical history.

\section{CASE}

A 26-year-old female non-smoker medical doctor with no medical history presented to the emergency clinic after developing sudden onset retrosternal chest pain during her COVID-19 night shift. She denied any trauma to the chest or abdomen in her medical history, and reported no tobacco or other substance use. She reported no other recent symptoms, including weakness, shortness of breath, fevers, chills, cough, abdominal or chest pain, nausea or vomiting, and had an insignificant family history. Around two weeks earlier she had taken a COVID-19 reverse transcriptase-polymerase chain reaction (RT-PCR) test (Bioeksen R\&D Technologies Inc. COVID-19 RT-qPCR Detection Kit v2.0, Istanbul, Turkey) and an anti-COVID19 antibody test [VIDAS Anti-SARS CoV-2 lgG and IgM (BioMérieux, Marcy-l'Etoile, France)] as a control due to her active employment in a COVID-19 clinic and her cohabitation with her family, and both test results were negative. A physical examination revealed a forward-bent posture, reducing body movement and preventing deep inspiration. Mild emphysema was detected on the right side of the neck skin; chest auscultation was normal; and other systemic examination findings were unremarkable. Her vitals were: $\mathrm{SpO}_{2} 97 \%$ in room air, body temperature $36{ }^{\circ} \mathrm{C}$, respiratory rate 22 breaths $/ \mathrm{min}$, heart rate 81 beats/min and blood pressure 110/70 mmHg. Electrocardiography revealed normal sinus rhythm and there were no signs of myocardial ischemia. A thin radiolucent line was noted on right side of an antero-posterior chest $\mathrm{X}$-ray (CXRs) with no pneumothorax findings (Figure 1). A chest computed tomography (CT) revealed diffuse air values in the mediastinum around the trachea and esophagus, extending to the hiluses. There was no infiltration of the lung parenchyma and no pleural or pericardial effusion was detected. No pneumothorax was observed, and other findings were normal (Figure 2). In order not to miss any acute cardiac pathology, a bedside echocardiography was performed, and left ventricular ejection fraction (LVEF), pulmonary artery pressures (PAP), in which all cardiac chamber sizes were found to be within the normal ranges, and no valve pathology was observed. Laboratory examinations revealed no abnormality in the routine biochemistry and complete blood count, and serum C-reactive protein, ferritin, procalcitonine, cardiac enzyme levels and coagulation test results were within the normal range. When the COVID-19 RT-PCR test and anti-COVID-19 $\lg G+\lg M$ test were performed again, the COVID-19 RT-PCR test was negative but the anti-COVID-19 lgG $+\lg M$ was $>10$, reactive (Normal $0_{-}$ 0.99). The patient was hospitalized with oxygen therapy by nasal canule, and $3 \times 1 \mathrm{gr}$ cefazolin antibiotherapy was initiated due to the risk of development of mediastinitis. The patient was monitored with a daily physical examination and antero-posterior CXRs. The chest pain and the emphysema detected on the neck skin dissipated on the fourth day of hospitalization. No pathology or any other symptoms were observed during follow-up. As the patient wanted to rest at home, she was discharged after receiving the recommendations of the thoracic surgery clinic. On the seventh day following discharge, the patient attended the post-COVID-19 outpatient clinic for control. She had no complaints, and no pathology was found during a physical examination and control anteroposterior CXRs (Figure 3).

\section{DISCUSSION}

WHO defines asymptomatic COVID-19 infection as a laboratory-confirmed infection with no overt symptoms (3) Asymptomatic COVID-19 infections are an significant aspect of COVID-19 due to the potential for the spread of infection, and those who come into contact with infected persons must be tested or followed up for COVID-19, regardless of the presence of symptoms. It is hard, however, to determine the true incidence of asymptomatic COVID-19 infections due to the need for close and widespread surveillance studies that must extend beyond the estimated average incubation period (4). 


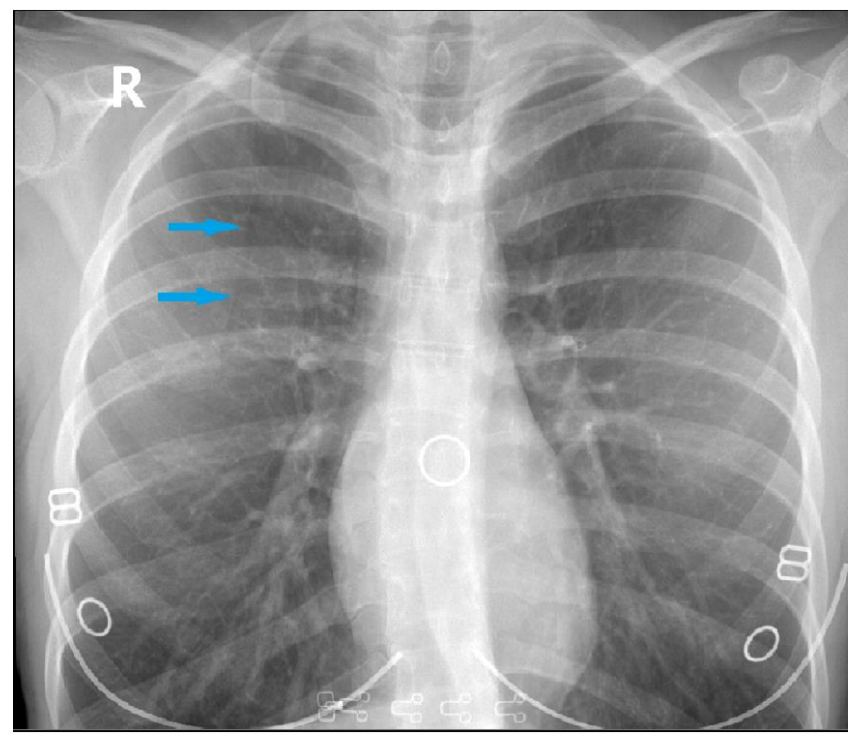

Figure 1: Antero-posterior CXRs first day, pneumomediastinum (arrow)

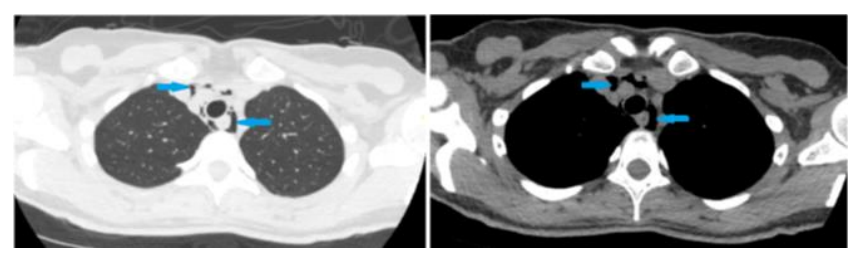

Figure 2: Pneumomediastinum on chest CT (arrows)

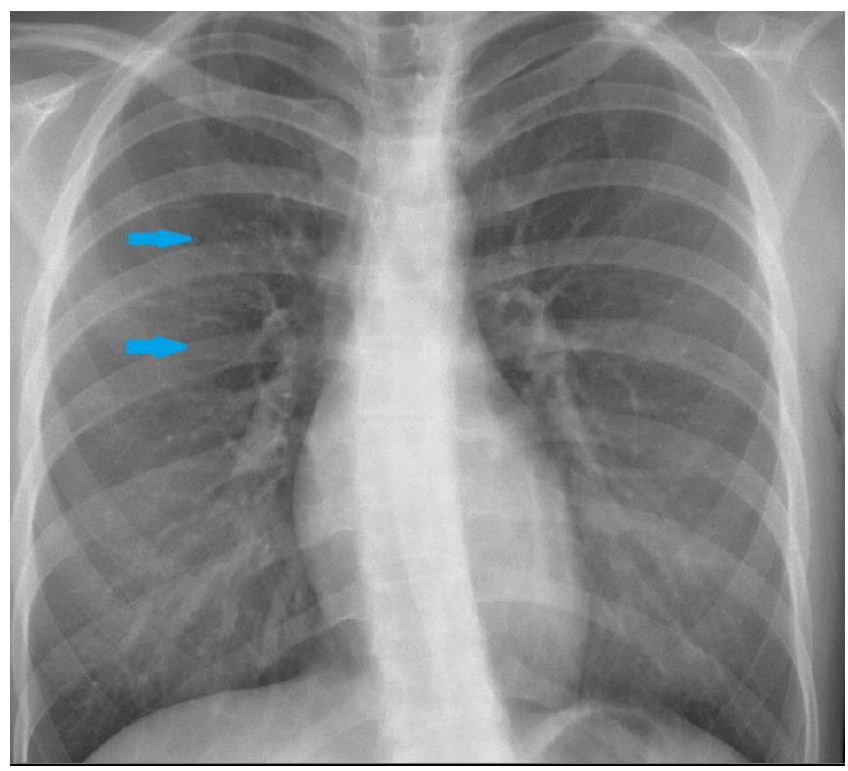

Figure 3: Antero-posterior CXRs on day 7 following discharge, with no sign of pneumomediastinum (arrows)

Although pneumomediastinum is often a self-limiting clinical situation, according to many theories, it can sometimes lead to life-threatening conditions such as tension pneumothorax and cardiac tamponade. Recent studies have reported pneumomediastinum to occur in COVID-19 cases as an uncommon complication, the mechanism of which cannot be fully explained (5).
Based on a systematic literature review, pneumomediastinum due to COVID 19 reports belonged to the hospitalized patients because of mild to severe COVID-19 infection. Even some of them had no etiological condition or positive pressure ventilation applications as a risk factor for spontaneous mediastinum (6). In the case presented here, the patient was non-hospitalized, had an asymptomatic COVID-19 infection and carried no risk factor for pneumomediastinum, and so is somewhat unique in literature. Based on the findings of this study, it can be emphasized that spontaneous pneumomediastinum should be kept in mind not only in mild to severe hospitalized COVID-19 cases, but also in asymptomatic nonhospitalized patients with sudden onset chest pain, and such cases should be evaluated with a physical examination and lung imaging.

\section{CONFLICTS OF INTEREST}

None declared.

\section{AUTHOR CONTRIBUTIONS}

Concept - M.V.C., S.Karaa., S.Karao., S.N.A., M.Ö.; Planning and Design - M.V.C., S.Karaa., S.Karao., S.N.A., M.Ö.; Supervision - M.V.C., S.Karaa., S.Karao., S.N.A., M.Ö.; Funding -; Materials -; Data Collection and/or Processing - M.Ö., S.N.A.; Analysis and/or Interpretation - M.V.C., S.Karaa., S.Karao.; Literature Review -; Writing - M.V.C., M.Ö., S.N.A.; Critical Review M.V.C., S.Karaa.

\section{YAZAR KATKILARI}

Fikir - M.V.C., S.Karaa., S.Karao., S.N.A., M.Ö.; Tasarım ve Dizayn - M.V.C., S.Karaa., S.Karao., S.N.A., M.Ö.; Denetleme - M.V.C., S.Karaa., S.Karao., S.N.A., M.Ö.; Kaynaklar -; Malzemeler -; Veri Toplama ve/veya İşleme M.Ö., S.N.A.; Analiz ve/veya Yorum - M.V.C., S.Karaa., S.Karao.; Literatür Taraması -; Yazıyı Yazan - M.V.C., M.Ö., S.N.A.; Eleştirel İnceleme - M.V.C., S.Karaa.

\section{REFERENCES}

1. Pooni R, Pandey G, Akbar S. Broadening the differential: pneumomediastinum and COVID-19 infection. BMJ Case Rep 2020; 13:e237938. [CrossRef]

2. Greenberg DJ, Nabors C, Chandy D, Dhand A. Pneumothorax and pneumomediastinum in patients hospitalized with coronavirus disease 2019 (COVID-19). Heart Lung 2021; 50):386-7. [CrossRef] 
3. World Health Organization.Clinical management of COVID-19: interim guidance, 2020. https://www.who.int/publications/i/item/clinicalmanagement-of-covid-19.

4. Nikolai LA, Meyer CG, Kremsner PG, Velavan TP. Asymptomatic SARS Coronavirus 2 infection: Invisible yet invincible. Int J Infect Dis 2020; 100:1 12-6. [CrossRef]

5. Lemmers DHL, Abu Hilal M, Bnà C, Prezioso C, Cavallo $E$, Nencini $N$, et al. Pneumomediastinum and subcutane- ous emphysema in COVID-19: barotrauma or lung frailty? ERJ Open Res 2020; 6:00385-2020. [CrossRef]

6. Quincho-Lopez A, Quincho-Lopez DL, Hurtado-Medina FD. Case report: pneumothorax and pneumomediastinum as uncommon complications of COVID-19 pneumonia-literature review. Am J Trop Med Hyg 2020; 103:1 170-6. [CrossRef] 